\title{
Two new species of Corynespora from Uttar Pradesh, India
}

\section{Kumar $S^{1,2 *}$, Singh $R^{2}$, Gond DK ${ }^{1}$ and Saini DC ${ }^{1}$}

${ }^{\mathbf{1} B i r b a l}$ Sahni Institute of Palaeobotany, 53, University Road, Lucknow-226007(U.P.), India.

${ }^{2}$ Department of Botany, D.D.U. Gorakhpur University, Gorakhpur-273009 (U.P.), India.

Kumar S, Singh R, Gond D, Saini DC 2012 - Two new species of Corynespora from Uttar Pradesh, India. Mycosphere 3(5), 864-869, Doi 10.5943 /mycosphere/3/5/11

This paper presents the descriptions and illustrations of two hitherto undescribed species of Corynespora Gussow viz., Corynespora annonacea sp. nov. and Corynespora holopteleicola sp. nov. collected on living leaves of Annona squamosa (Annonaceae) and Holoptelea integrifolia (Ulmaceae) respectively from Uttar Pradesh, India.

Key words - Corynespora - Foliicolous hyphomycete - Fungi - Morphotaxonomy - New species

\section{Article Information}

Received 14 September 2012

Accepted 16 September 2012

Published online 16 October 2012

*Corresponding author: Shambhu Kumar - e-mail - skumartaxon@gmail.com

\section{Introduction}

The foliicolous hyphomycetous genus Corynespora was established by Gussow (1906). The genus is found predominatly in tropics and subtropics including India, and is characterized by producing distoseptate conidia with or without distinct hila. The species of Corynespora range from saprotrophs to necrotrophs and to biotrophs. As parasites or biotrophs they assume great importance infecting different parts of the plant particularly living leaves. The area of leaf invaded by foliicolous hyphomycetes such as Corynespora usually become distinct due to the presence of fungus itself and the various local host responses ranging from discolouration to necrosis as the result. The leaf spots vary in colour, shape, size and other features of appearance depending upon the degree and type of hostparasite interaction and association.

Many novel species of Corynespora have been described from India (Meenu et al. 1997, 1998 Sarbhoy et al. 1996, Meenu \&
Kamal 1998, Singh et al. 2000 a, b, 2007a, b, Sharma et al. 2002a, b, 2003, 2005, Jain et al. 2002, Dubey \& Rai 2003, Jamaluddin et al. 2004, Kumar et al. 2007, 2008, 2012, Pal et al. 2007, Verma et al. 2008, Singh \& Mall 2011, Singh \& Kamal 2012). This paper is a continuation of the aforesaid contributions.

During our survey (2007-2009) of Uttar Pradesh, many collections showing foliar disease have been encountered, included amongst were two undescribed taxa of Corynespora. Descriptions and illustrations of these taxa are presented in the communication.

\section{Methods}

Surface scrapping and free hand cut sections were taken through infection spots and mounted in lactophenol cotton-blue mixture for microscopic examination, camera lucida drawing and micrometry. Type specimens have been deposited in HCIO, IARI, New Delhi and their isotopes have been retained in the departmental herbarium. 


\section{Results}

\section{Taxonomy}

Corynespora annonacea Sham. Kumar, R. Singh, Gond \& Saini sp. nov.

Fig. 1

MycoBank MB 800578

Infection spots amphigenous, circular to irregular, brown on upper surface with dark brown margin, light brown on lower surface, later becoming necrotic, $2-20 \mathrm{~mm}$ in diam. Colonies amphiphyllous, effuse, dark grey. Mycelium internal, septate, smooth, thinwalled, branched, subhyaline to pale brown. Stromata absent. Conidiophores macronematous, mononematous, arising singly, straight to curved, erect to procumbent, simple to branched, cylindrical, thick-walled, 2-4euseptate with 0-3 successive cylindrical proliferations, basal cell swollen, light to dark olivaceous brown, 195-260 $\mu \mathrm{m}$ long and 5-9 $\mu \mathrm{m}$ wide. Conidiogenous cells integrated, terminal, monotretic, scars thickened to unthickened. Conidia solitary to catenate, dry, acrogenous, simple, smooth, thin-walled, straight to curved, obclavate to obclavatocylindrical, apex obtuse to rounded, base truncate, 1-10 distoseptate with $0-1$ distinct constriction, hilum unthickened, subhyaline to olivaceous brown, $25-135 \times 10-18 \mu \mathrm{m}$ in diam, germinating conidia present.

Type - On living leaves of Annona squamosa L. (Annonaceae), University Campus, Gorakhpur (U.P.), India, February, 2008, coll. Shambhu Kumar, GPU-KSR 111 (isotype), HCIO 48273 (holotype).

the host genus.

Etymology - annonacea in reference to

A literature survey indicated that no species of Corynespora have been described on this host and host family. Therefore, the morphotaxonomic comparison is done with type species $C$. cassicola (Berk. \&Curt.) Wei (1950).

The conidiophores of present collection are much shorter, fewer septate and fiewer proliferations in comparison to the type species C. cassicola, in which conidiophores are longer $(110-850 \times 4-11 \mu \mathrm{m})$, multiseptate with 9 successive proliferations. The conidiophores are branched in $C$. annonacea while they are unbranched in $C$. cassicola. The conidia of the new species are shorter than those of $C$. cassicola $(40-220 \times 9-11 \mu \mathrm{m})$. Therefore, proposal of $C$. annonacea as a new taxon of species rank is found to be justified.

Corynespora holopteleicola Sham. Kumar, R. Singh, Gond \& Saini sp. nov.

MycoBank MB 800579

Fig. 2

Infection spots amphigenous, subcircular to irregular, brown to dark brown, 2-18 $\mathrm{mm}$ in diam. Colonies amphiphyllous, effuse, greyish. Mycelium internal to external, branched, septate, subhyaline to brown. Stromata absent. Conidiophores macronematous, mononematous, arising singly, erect to procumbent, straight to flexuous, simple to branched, smooth, thick-walled, 2-4 euseptate with $0-4$ successive cylindrical proliferations, base swollen olivaceous brown, hilum unthickened 120-255 $\mu \mathrm{m}$ long and 5-20 $\mu \mathrm{m}$ wide. Conidiogenous cells integrated, terminal, scar thickened. Conidia monoblastic, acrogenous, dry, simple, solitary, smooth, thin-walled, straight to curved, obclavate to obclavatocylindrical, apex obtuse to rounded, base rounded, 0-11 distoseptate with 0-2 distinct septate, olivaceous brown, hilum unthickened, 33-148 × 5-20 $\mu \mathrm{m}$.

Type - On living leaves of Holoptelea integrifolia Roxb. (Ulmaceae), University Campus, Gorakhpur (U.P.) India, January 2008, coll. Shambhu Kumar, GPU-KSR112 (isotype), HCIO 48274 (holotype)

Etymology - holopteleicola in reference to the host genus.

Another species Corynespora holopetae has been described on the same host. (Jain et al. 2002).

However, the conidiophores are shorter in $C$. holopteleicola than those in $C$. holopetae (49-314 $\times 5-9 \mu \mathrm{m}$.). The conidia of $C$. holopteleicola are also shorter $(33-148 \times 5-20$ $\mu \mathrm{m})$ than those of $C$. holopetae $(23-234 \times 3.5$ $20 \mu \mathrm{m}$.). There are fewer distosepta in conidia of $C$. holopteleicola than in C. holopetae (up to 17). The conidial scar is unthickened in $C$. holopteleicola while it is thickened in $C$. holopetae. Therefore, it merits recognition as a new taxon at species rank. 


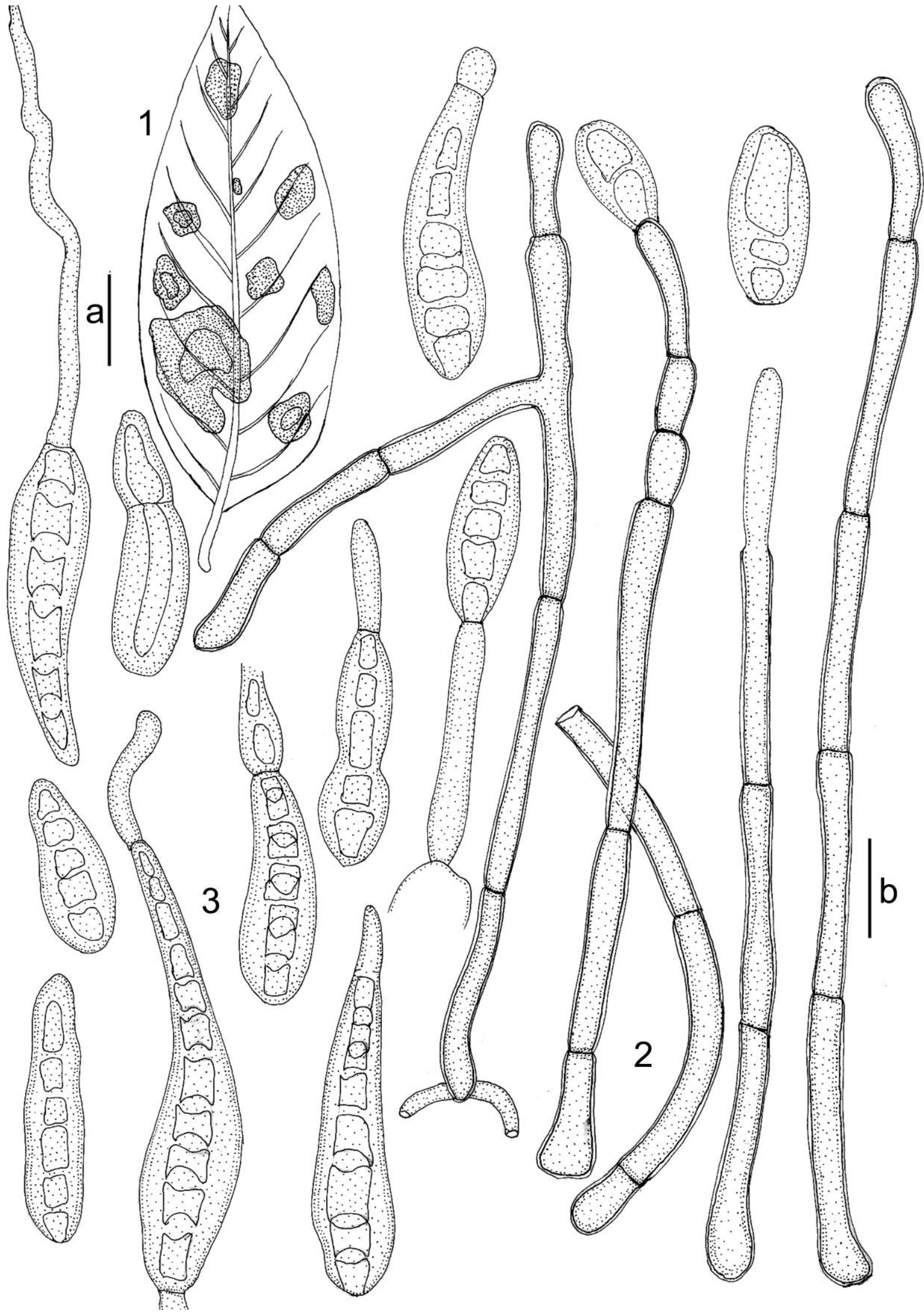

Fig. 1 - Corynespora annonacea. 1 Infection spots. 2 Conidiophores. 3 Conidia. Bars a = 20 mm, b $=20 \mu \mathrm{m}$. 
Mycosphere Doi 10.5943/mycosphere/3/5/11

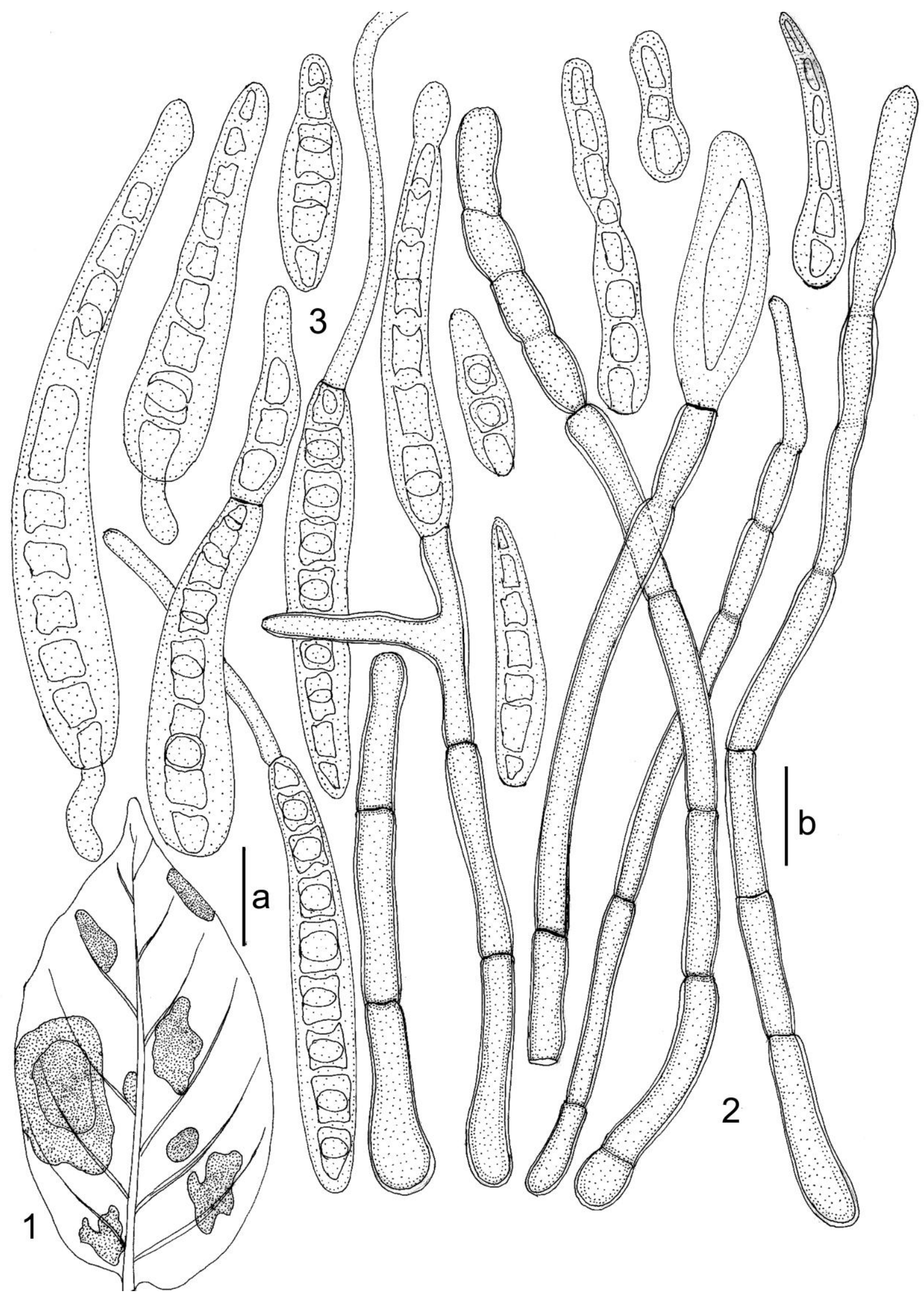

Fig. 2 - Corynespora holopteleicola. 1 Infection spots. 2 Conidiophores. 3 Conidia. Bars a = 20 $\mathrm{mm}, \mathrm{b}=20 \mu \mathrm{m}$. 


\section{Acknowledgements}

Authors are grateful to the Head, Department of Botany, DDU Gorakhpur University, Gorakhpur and Director, Birbal Sahni Institute of Palaeobotany for providing library and laboratory facilities. Author's thanks are also due to the Curator, HCIO, IARI, New Delhi for depositing the holotype specimens and providing accession numbers thereof and Uttar Pradesh State Biodiversity Board for assistant to first author.

\section{References}

Dubey RK, Rai AN. 2003 - Two new hyphomycetous fungi from India. Indian Phytopathology 56, 486-490.

Gussow HT. 1906 - Uber eine neue Krankeit aliquot Gurken in England (Corynespora mazei, Gussow gen. et sp. nov.). Zeitschrift für Pflanzenkrankheiten 16, 10-13.

Jain SL, Rai AN, Mehta P. 2002 - Additions to the genus Corynespora from India. Indian Phytopathology 55, 51-56.

Jamaluddin, Goswami MG, Ojha BM. - 2004. Fungi of India 1989-2001, Scientific Publishers, Jodhpur, India, pp 326.

Kumar S, Singh R, Pal VK. 2007 - Three hitherto undescribed species of Corynespora from North-Eastern Uttar Pradesh. Journal of Basic \& Applied Mycology 6, 39-43.

Kumar S, Singh R, Singh DP, Pal VK, Agarwal DK. 2008- Additions to new species of Corynespora Gussow from NorthEastern Uttar Pradesh. Indian Phytopathology 61, 111-117.

Kumar S, Singh R, Saini, DC, Kamal. 2012. A new species of Corynespora from terai forest of northeastern Uttar Pradesh, India. Mycosphere 3, 410-412.

Meenu, Kamal. 1998 - New species of Corynespora. Mycological Research 102, 344-345.

Meenu, Singh A, Singh SK. 1997 - Some new forms of genus Corynespora. Indian Phytopathology 50, 17-24.

Meenu, Kharwar RN, Bhartiya HD. 1998 Some new forms of genus Corynespora from Kathmandu valley of Nepal. Indian Phytopathology 51,
146-151.

Pal VK, Akhtar M, Agarwal DK, Chaudhary RK, Ahmad N. 2007 - Diversity of foliar fungi in the forest flora of NorthEastern U.P: Five new species of Corynespora Gussow. Indian Phytopathology 60, 330-340.

Sarbhoy AK, Agarwal DK, Varshney JL. 1996 - Fungi of India (1982-1992). CBS Publishers and Distributors, New Delhi. pp 350.

Sharma N, Chaudhary RK, Kamal. 2002a Three new species of genus Corynespora. Indian Phytopathology 55, 178-181.

Sharma N, Chaudhary RK, Kamal. 2002b Five undescribed species of Corynespora. Indian Phytopathology 55, 458-463.

Sharma N, Singh PN, Kamal. 2003 - Three new taxa of Corynespora causing foliar blight in forest plants of NorthEastern Uttar Pradesh. Journal of Mycology \& Plant Pathology 33, 2632.

Sharma N, Soni KK, Verma RK, Jamaluddin 2005 - A new species of Corynespora from central India. Indian Phytopathology 58, 503-504.

Singh A, Bhalla K, Dubey R, Singh SK. 2000a - Additions to Corynespora from India. Journal of Indian Botanical Society 79, 185-190.

Singh A, Singh SK, Kamal. 2000b- Additions to Corynespora from India. Journal of Mycology \& Plant Pathology 30, 4449.

Singh, DP, Mall TP. 2011 - Two novel additions to Corynespora Gussow from India. International Journal of Plant Sciences 6, 321-324.

Singh R, Kamal. 2012 -Two new species of Corynespora from northeastern U.P., India. Mycotaxon 118, 123-129.

Singh R, Kumar S, Pal VK, Upadhyaya PP, Agarwal DK. 2007a - New taxa of follicolous hyphomycetes- Cercospora, Corynespora and Phaeotricoconis from North Eastern U.P. India. Indian Phytopathology 60, 506-512.

Singh R, Kumar S, Shukla K, Agarwal DK. 2007b - Three hitherto undescribed 
Mycosphere Doi 10.5943/mycosphere/3/5/11

species of Corynespora Gussow from

North Eastern U.P. Indian Phytopathology 60, 513-519.

Verma RK, Sharma N, Soni KK, Jamaluddin 2008 - Forest fungi of Central India.
International Book Distributing Company, Lucknow, India, pp. 418.

Wei CT. 1950 - Note on Corynespora, Mycological Papers 34, 1-9. 